\title{
JURIANAI
}

Jurnal Pendidikan Ekonomi

$\therefore$ JUR KAIMI

VOLLME

5
NOMOR

2

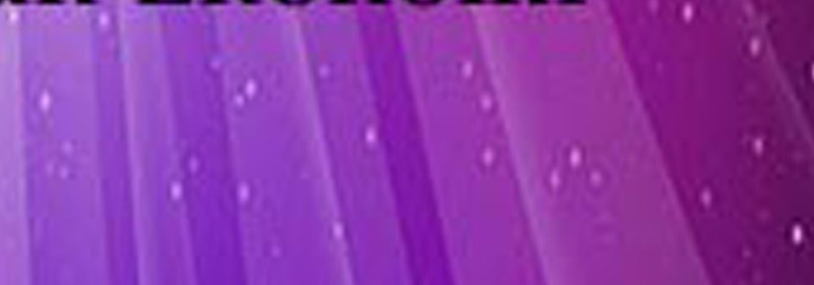




\title{
JURKAMI:Jurnal Pendidikan Ekonomi
}

http://jurnal.stkippersada.ac.id/jurnal/index.php/JPE

JURKAMI Volume 5, No 2, 2020

\section{PENGARUH KUALITAS PELAYANAN KOPERASI TERHADAP MINAT MENABUNG ANGGOTA KOPERASI KREDIT BINA MASYARAKAT CABANG SINTANG}

\author{
Brigita Fitri ${ }^{1}$, Dessy Triana Relita ${ }^{2}$ \\ STKIP Persada Khatulistiwa Sintang, Indonesia ${ }^{12}$ \\ Email: brigitafitri26@gmail.com; dssytriana.relita@gmail.com
}

Diterima: 23 Oktober 2020; Disetujui: 29 Oktober 2020; Diterbitkan: 1 November 2020

\begin{abstract}
This study aimed to determine the effect of service quality on members' interest in saving. This research was quantitative research. The population was 610 members of the CU BIMA Cabang Sintang who saved. The number of samples was 98 respondents, the sampling technique used simple incidental. First, data analysis was done by looking for validity and reliability, descriptive analysis test, contribution test, and classical assumption test. The data obtained processed by SPSS program 18 version. The results showed that the quality of service had an effect on the saving interest of members of the CU BIMA Cabang Sintang, with the results of the t test, it is obtained that the value of t count 3.824 is greater than (>) t table 1.984 and the value of Sig. $0.000<0.05$
\end{abstract}

\section{Keywords: Service Quality, Saving Interest}

Abstrak: Penelitian ini bertujuan untuk mengetahui pengaruh kualitas pelayanan terhadap minat menabung anggota. Penelitian ini termasuk jenis penelitian kuantitatif. Populasi pada penelitian ini adalah anggota CU BIMA Cabang Sintang sebanyak 610 orang yang menabung. Jumlah sampel dalam penelitian ini sebanyak 98 responden, teknik pengambilan sampel yang digunakan adalah simple insidental. Analisis data terlebih dahulu dilakukan dengan mencari validitas dan reliabilitas, uji analisis deskriptif, uji kontribusi, serta uji asumsi klasik. Data yang diproleh diolah dengan program SPSS versi 18. Hasil penelitian menunjukan bahwa kualitas pelayanan berpengaruh terhadap minat menabung anggota CU BIMA Cabang Sintang, dengan hasil uji t, diperoleh nilai $t_{\text {hitung }}$ 3,824 lebih besar dari (>) $t_{\text {tabel }} 1,984$ dan nilai Sig. $0,000<0,05$.

Kata Kunci: Kualitas Pelayanan, Minat Menabung 
PENDAHULUAN

Koperasi Kredit Bina Masyarakat yang disingkat dengan KOPDIT BIMA adalah badan usaha koperasi kredit primer yang bergerak pada bidang pelayanan keuangan kepada anggota. CU Bima merupakan salah satu koperasi yang pertama hadir dengan harapan ekonomi masyarakat bisa diberdayakan melalui kesadaran menabung. Tujuan untuk memperbaiki tatanan kehidupan masyarakat Kabupaten Sintang. Koperasi Kredit Bina Masyarakat Cabang Sintang memperoleh Badan Hukum Nomor: 1555/BH/X/1995 dari Kanwil Provinsi Kalimantan Barat. Jumlah anggota Kopdit Bima Cabang Sintang hingga tahun 2020 sebanyak 610 orang. Menurut laporan pertanggung jawaban tahun buku 2020, Kopdit Bima Cabang Sintang memiliki karyawan sebanyak 9 orang. Produk simpanan yang ada di KOPDIT BIMA seperti Simpanan Sejahtera Anggota (SSA), Simpanan Taktis (SINTAK), Tabungan Beasiswa (TAWA), Simpanan Masa Tua (SIMATU), Simpanan Perkebunan (SIBUN), Simpanan Sukarela Berjangka.

Berdasarkan hasil observasi awal, peneliti menemukan beberapa permasalahan yang dihadapi Koperasi Kredit Bina Masyarakat Cabang Sintang. Hasil yang peneliti temukan di lapangan yaitu terjadi ketimpangan terhadap pelayanan yang diberikan karyawan koperasi dengan yang diharapkan oleh anggota koperasi. Dengan jumlah anggota sebanyak 610 orang dan karyawan 9 orang, serta dibantu oleh beberapa karyawan dari kantor pusat. Kopdit Bima masih mengalami kesulitan dalam memberikan pelayanan yang cukup kepada anggota dan mengakibatkan ada beberapa anggota yang merasa tidak puas terhadap pelayanan karyawan. Jumlah anggota CU juga tidak sesuai target pada tahun 2019 dimana hal tersebut disebabkan oleh banyaknya lembaga keuangan sejenis serta pelayanan yang diberikan berbeda-beda. CU Bima juga mengalami penurunan beberapa pos pada tahun 2019 namun pada simpanan saham mengalami peningkatan yaitu pada tahun 2020. Salah satu karyawan CU Bima mengatakan bahwa kantor cabang sudah melakukan analisis terhadap penyebab keluarnya anggota dari KOPDIT BIMA setiap tahunya, namun belum ditemukan apakah karena pelayanan atau produk simpanan pada CU Bima.

Kualitas pelayanan menjadi salah satu prioritas yang menjadi pertimbangan dalam suatu bidang usaha yaitu seperti perkoperasian.

Menabung sebagai kegiatan menyimpan uang dalam tabungan di kantor baik Koperasi, Pos, Bank dan sebagainya. Menyimpan uang merupakan suatu tujuan untuk memenuhi kebutuhan 
pada masa yang akan datang. Menurut Handayani (2018:4) "Minat menabung merupakan bagian atau salah satu elemen penting dari perilaku anggota dalam menilai, mendapatkan dan mempergunakan barang-barang serta jasa ekonomi”. Menurut Sumantri (2014: 142) menyatakan bahwa "Meningkatkan suatu badan usaha tidak hanya didukung oleh sumberdaya manusia yang profesional dan memiliki pengalaman praktis dalam bidangnya, akan tetapi juga dipengaruhi faktor-faktor lain. Faktor-faktor tersebut antara lain, kesadaran masyarakat untuk berbisnis dan menabung" Darmawan (2019:43-47) "Minat menabung anggota dapat dipengaruhi oleh beberapa faktorfaktor seperti kepercayaan terhadap suatu produk, bagi hasil, fasilitas pelayanan, promosi dan pendapatan".

Masalah kualitas pelayanan bukanlah hal yang sulit, tetapi apabila pelayanan tersebut kurang diperhatikan maka dapat menimbulkan hal-hal yang fatal karena sifatnya sangat sensitif. Sistem pelayanan yang diberikan perlu adanya dukungan oleh daya tanggap, respon, fasilitas yang memadai dan etika atau tata krama dari pihak karyawan maupun pengurus koperasi. Sedangkan tujuan memberikan pelayanan adalah untuk mempertahankan anggota yang sudah ada dan untuk menarik minat masyarakat menabung di koperasi, sehingga berakibat dengan di hasilkannya nilai tambah bagi koperasi itu sendiri. Ada banyak faktor yang dapat menyebabkan rendahnya minat menabung anggota di Koperasi. Kualitas pelayanan menjadi menarik untuk dibahas dalam penelitian ini, karena kemungkinan besar menjadi salah satu faktor pertimbangan bagi anggota untuk bertahan dan memilih menabung di koperasi.

Berdasarkan penelitian terdahulu dilakukan oleh Angger (2018:7) dalam penelitiannya yaitu "Dengan meningkatkan kepuasan anggota terhadap pelayanan yang diberikan, maka akan memberikan dampak yang baik bagi koperasi yaitu meningkatnya minat menabung anggota”. Menurut Tyas dan Setiawan dalam (Nugroho 2018:3) menyatakan bahwa yaitu "Hasil penelitiannya menunjukan kualitas pelayanan berpengaruh terhadap keputusan menabung anggota". Sejalan dengan hasil penelitian Handayani menunjukan bahwa "Kualitas produk tabungan dan Kualitas pelayanan secara parsial menunjukkan pengaruh yang positif dan signifikan terhadap minat menabung anggota".

Berdasarkan uraian latar belakang di atas, serta untuk mengkaji lebih dalam mengenai kualitas pelayanan yang di berikan oleh karyawan di CU BIMA, maka peneliti tertarik untuk melakukan penelitian dengan judul "Pengaruh 
Kualitas Pelayanan Koperasi terhadap Minat Menabung Anggota Koperasi Kredit Bina Masyarakta (KOPDIT BIMA) Cabang Sintang”

\section{KAJIAN TEORI}

Menurut Baswir (2015:21) menyatakan, "Koperasi secara etimologi berasal dari kata cooperation, yang artinya bekerja bersama-sama atau usaha bersama untuk kepentingan bersama". UndangUndang No. 25 tahun 1992 Bab 1 Pasal 1 Menyatakan bahwa Koperasi adalah badan usaha yang beranggotakan orang-orang atau badan hukum koperasi dengan melandaskan kegiatannya berdasarkan prinsip koperasi, sekaligus sebagai gerakan ekonomi rakyat yang berdasarkan asas kekeluargaan.

Menurut Kholid dan Rahayu (2014:2) menyatakan bahwa Pengertian koperasi adalah sekumpulan orang yang dengan sukarela mengikutkan dirinya untuk bersama-sama mensejahterakan anggotanya dengan melakukan kegiatan secara kekeluargaan dan demokratis.

Menurut Mintarja, E. (2017:192193) menyatakan bahwa Minat menabung adalah suatu tindakan sukarela (tanpa ada paksaan) dan ketertarikan untuk menggunakan jasa layanan atau fasilitas layanan koperasi, baik sebagai pemilik modal (menabung) atau sebagai pihak yang membutuhkan modal (Pembiayaan).
Menurut Lovelock dalam (Tyas dan Setiawan 2012:283) sebagai berikut Kualitas pelayanan merupakan tingkatan kondisi baik buruknya sajian yang diberikan oleh perusahaan jasa dalam rangka memuaskan konsumen dengan cara memberikan atau menyampaikan jasa yang melebihi harapan konsumen. Menurut Arif dalam (Aswati \& Sudarso, 2019:64) Menyatakan bahwa, "Kualitas pelayanan merupakan perbandingan antara layanan yang dirasakan sama atau melebihi kualitas layanan yang diharapkan, maka layanan dapat dikatakan berkualitas dan memuaskan". Adapun indikator kualitas pelayanan anggota yang digunakan dalam penelitian ini adalah:

1. Tangibles (Bukti Langsung)

2. Reliability (Keandalan),

3. Rensponsiveness (Ketanggapan),

4. Assurance (Jaminan), dan

5. Empathy (Empati).

\section{METODOLOGI PENELITIAN}

Metode penelitian yang digunakan peneliti adalah Metode penelitian deskriptif kuantitatif dengan menggunakan pendekatan Assosiatif. Bentuk penelitian yang digunakan adalah penelitian korelasi atau korelasional. Penelitian dilaksanakan di Koperasi Kredit Bina Masyarakat Cabang Sintang yang sampai saat ini berjumlah 610 orang anggota penabung, 
dengan teknik pengambilan sampel oleh peneliti menggunakan sampling insidental.

Teknik pengumpulan data yang digunakan adalah Tekni Angket dan Teknik Dokumentasi. Alat pengumpulan data yang digunakan adalah lembar angket dan lembar dokumentasi. Sedangkan Metode analisis data yang digunakan dalam penelitian ini adalah menggunakan analisis deskriptif statistik dan statistik inferensial yang terdiri dari uji asumsi klasik meliputi uji normalitas dan uji linieritas, analisis regresi sederhana,uji korelasi serta uji hipotesis yang meliputi Uji t dan koefisien determinasi.

\section{HASIL DAN PEMBAHASAN}

Hasil

Untuk melihat sebaran data hasil Penelitian berdasarkan indikator variabel kualitas pelayanan (X), dapat dilihat pada tabel berikut ini:

Tabel 1: Tabel Indikator Kualitas Pelayanan

\begin{tabular}{lccc}
\hline Indikator & Jumlah Skor & Persen & Skor Max \\
Tangible (Bukti Langsung) & 2162 & $77,21 \%$ & 2800 \\
Emphaty (Empati) & 1620 & $77,14 \%$ & 2100 \\
Responsivenes (Daya Tanggap) & 1639 & $78,04 \%$ & 2100 \\
Assurance (Jaminan) & 822 & $82,20 \%$ & 1000 \\
Reliability (Kehandalan) & 1597 & $79,85 \%$ & 2000 \\
Jumlah & 7840 & $78,40 \%$ & 10000 \\
\hline
\end{tabular}

Berdasarkan tabel 1 di atas dapat disimpulkan hasil angket penelitian variabel kualitas pelayanan (X) menunjukan nilai persentase dari indikator angket penelitian. Indikator Tangible (Bukti Langsung) sebesar 77,21\%, Indikator Emphaty (Empati) sebesar $77,14 \%$, Indikator Responsivenes (Daya Tanggap) sebesar 78,04\%, Indikator Assurance (Jaminan) sebesar 82,20\%, Indikator Reliability (Kehandalan) sebesar $79,85 \%$, Selanjutnya, nilaipresentase angketkeseluruhan sebesar 78,40\%.
Selanjutnya, nilai presentase angketkeseluruhan sebesar 78,40\% berada pada kategori besar Artinya bahwa kualitas pelayanan di Koperasi Kredit Bina Masyarakat Cabang Sintang dalam memberikan pelayanan kepada anggota dan masyarakat untuk menabung dikatakan besar atau baik dan sudah sesuai dengan harapan anggota, sehingga anggota menilai bahwa kualitas pelayanan CU BIMA sudah menjadi salah satu badan usaha koperasi yang menjadi kriteria yang baik. 
Tabel 2.Deskripsi Minat Menabung (Y)

\section{Indikator}

Kepercayaan terhadap suatu produk

Bagi Hasil

Kualitas Pelayanan

Promosi

Pendapatan

Jumlah

$\begin{array}{ccc}\text { Jumlah Skor } & \text { Persen } & \text { Skor Max } \\ 1680 & 70,00 \% & 2400 \\ 1705 & 68,20 \% & 2500 \\ 1263 & 70,17 \% & 1800 \\ 954 & 68,14 \% & 1400 \\ 1304 & 68,63 \% & 1900 \\ 6906 & 69,06 \% & 10000\end{array}$

Berdasarkan tabel 2 di atas dapat diketahui hasil angket penelitian variabel minat menabung (Y) menunjukan nilai persentase dari indikator angket penelitian. Indikator Kepercayaan terhadap suatu produk sebesar 70,00\%, Indikator Bagi Hasil sebesar 68,20\%, Indikator Kualitas Pelayanan sebesar 70,17\%, Indikator Promosi sebesar 68,14\%, Indikator Pendapatan sebesar 68,63\%, Selanjutnya, nilai presentase angket keseluruhan sebesar 69,06\% berada pada kategori besar sehingga disimpulkan bahwa minat menabung anggota di Koperasi Kredit Bina Masyarakat Cabang Sintang sudah memiliki jumlah anggota penabung yang banyak atau sesuai dengan yang diharapkan oleh pengurus dan karyawan.

Pengujian hipotesis dilakukan dengan uji t.pada penelitian ini hasil uji hipotesis dapat dilihat pada tabel berikut:

\section{Tabel 3. Uji t}

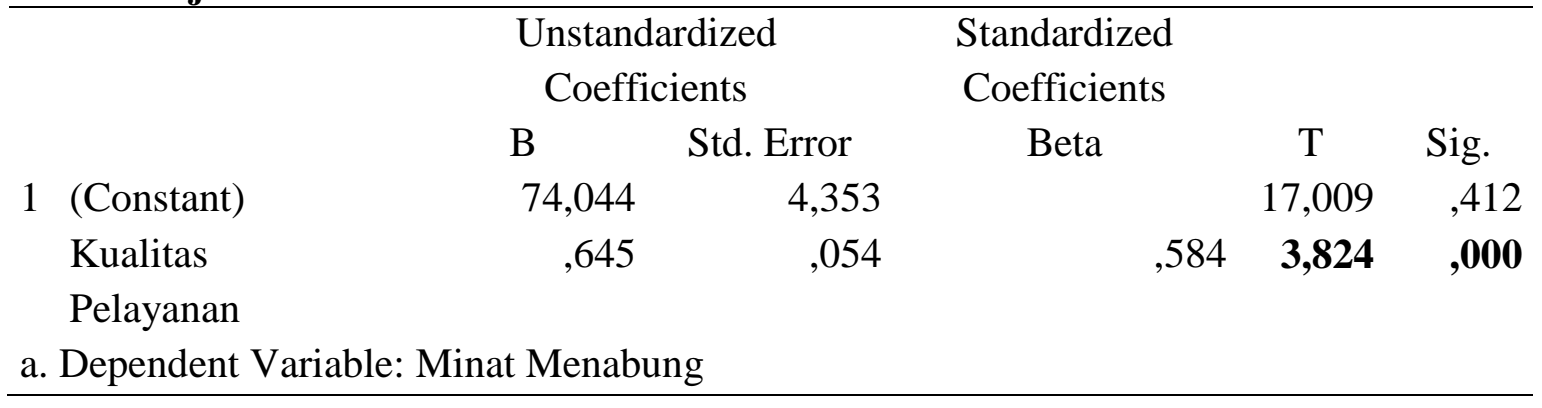

Berdasarkan tabel diatas diketahui hasil uji t yang dilakukan menghasilkan nilai $t_{\text {hitung }}$ sebesar 3,824 dengan Sig. Sebesar 0,000 dan taraf kesalahan 0,05 dan derajat kebebasan $\mathrm{dk}=\mathrm{n}-2$ 98-2=96 maka diperoleh nilai $t_{\text {tabel }}$ sebesar 1,984.
Berdasarkan hasil perhitungan $t_{\text {hitung }}$ $3,824>\mathrm{t}_{\text {tabel }} 1,984$, Artinya pada penelitian ini menerima hipotesis alternatif $\left(\mathrm{H}_{\mathrm{a}}\right)$ dan menolak hipotesis nol $\left(\mathrm{H}_{\mathrm{o}}\right)$, artinya bahwa terdapat pengaruh yang signifikan antara kualitas pelayanan koperasi terhadap minat menabung anggota Koperasi. Artinya 
JURKAMI:Jurnal Pendidikan Ekonomi

bahwa terdapat pengaruh yang signifikan antara kualitas pelayanan koperasi terhadap minat menabung anggota Koperasi Kredit Bina Masyarakat Cabang Sintang di Kecamatan Sintang, Kabupaten Sintang.

Tabel 4. Model Summary

\begin{tabular}{cccccc}
\hline Model & $\mathrm{R}$ & R Square & $\begin{array}{c}\text { Adjusted R } \\
\text { Square }\end{array}$ & $\begin{array}{c}\text { Std. Error of the } \\
\text { Estimate }\end{array}$ \\
\hline Dimension 0 & 1 &, $604^{\mathrm{a}}$ & $\mathbf{, 4 8 3}$ &, 240 & 3,855 \\
\hline
\end{tabular}

Berdasarkan tabel 4 di atas hasil uji output determinasi, didapatkan nilai $R$ Square sebesar 0,483 yang artinya pengaruh kualitas pelayanan (X) terhadap variabel minat menabung (Y) sebesar 48,3\%. Nilai uji determinasi di dapatkan dari nilai $R$ Square X100\%, maka didapatkan nilai variabel kualitas pelayanan $(\mathrm{X})$ terhadap variabel minat menabung (Y) sebesar 48,3\% dan sebesar $51,7 \%$ dipengaruhi oleh faktor lain yang tidak diteliti dalam penelitian ini.
JURKAMI Volume 5, no 2, 2020 | 143

Besarnya pengaruh kualitas pelayanan koperasi terhadap minat menabung anggota dapat diketahui melalui nilai koefisien determinasi. Adapun hasil perhitungan koefisien determinasi variabel kualitas pelayanan dan minat menabung dapat dilihat pada tabel berikut:

\section{Tabel 5. Hasil Uji Regresi Sederhana}

\begin{tabular}{llrrrrr}
\hline \multicolumn{9}{c}{ Unstandardized } & \multicolumn{2}{c}{ Standardized } \\
& Coefficients & Coefficients & & \\
1 (Constant) & B & Std. Error & Beta & \multicolumn{1}{c}{ T } & \multicolumn{1}{c}{ Sig. } \\
& $\mathbf{7 4 , 0 4 4}$ & 4,353 & & & 17,009 &, 412 \\
Kualitas Pelayanan & $\mathbf{6 4 5}$ &, 054 & &, 584 & 3,824 &, 000 \\
a. Dependent Variable: Minat Menabung & & & & & \\
\hline
\end{tabular}

Berdasarkan tabel 5 diperoleh nilai konstanta untuk persamaan regresi ini adalah 74,044 dan nilai koefisien kualitas pelayanan (X) sebesar 0,645 sehingga
Data penelitian yang telah diuji prasyarat analisis, analisis regresi sederhana dan uji asumsi klasik, kemudian diuji regresi linear sederhana untuk mengetahui persamaan regresi dari penelitian ini. Analisis regresi sederhana digunakan untuk mengetahui ketergantungan suatu variabel dependen yaitu minat menabung terhadap variabel independen yaitu kualitas pelayanan. Hasil analisis regresi sederhana dapat dilihat pada tabel berikut: 
nilainya 0 , maka nilai untuk variabel minat menabung (Y) sebesar 74,044. Nilai koefisien variabel kualitas pelayanan $(\mathrm{X})$ sebesar 0,645. Artinya jika kualitas pelayanan (X) mengalami peningkatan $1 \%$, maka minat menabung (Y) anggota akan mengalami kenaikan sebesar 0,645. Nilai positif pada nilai koefisien menunjukkan arah hubungan yang positif antara kualitas pelayanan koperasi dengan minat menabung anggota.

\section{Pembahasan}

Berdasarkan hasil penelitian yang telah dilakukan oleh peneliti, dengam jumlah sampel peneliti sebanyak 98 orang anggota koperasi, diperoleh hasil dari kualitas pelayanan pada Koperasi Kredit Bina Masyarakat Cabang Sintang dalam kategori sangat besar., diperoleh hasil angket penelitian variabel kualitas pelayanan $(\mathrm{X})$ menunjukan nilai presentase keseluruhan sebesar $78,40 \%$ yang dikategorikan besar. Jadi, dapat disimpulkan bahwa kualitas pelayanan pada Koperasi Kredit Bina Masyarakat Cabang Sintang dalam memberikan pelayanan kepada anggota dan masyarakat untuk menabung dikatakan besar atau baik dan sudah sesuai dengan harapan anggota, sehingga anggota menilai bahwa kualitas pelayanan CU BIMA sudah menjadi salah satu badan usaha koperasi yang menjadi kriteria yang baik.
Minat menabung anggota Koperasi Kredit Bina Masyarakat Cabang Sintang. Menurut Darmawan (2019:43-47) "Minat menabung anggota dapat dipengaruhi oleh beberapa faktor-faktor seperti kepercayaan terhadap suatu produk, bagi hasil, fasilitas pelayanan, promosi dan pendapatan". Berdasarkan hasil penelitian yang telah dilakukan peneliti dengan jumlah sampel penelitian yang diperoleh sebanyak 98 orang anggota Koperasi Kredit Bina Masyarakat (KOPDIT BIMA) Cabang Sintang, diperoleh hasil angket penelitian variabel minat menabung (Y) anggota dengan hasil nilai presentase keseluruhan sebesar 69,06\% yang diketegorikan besar. Jadi, dapat disimpulkan bahwa minat menabung anggota pada Koperasi Kredit Bina Masyarakat (KOPDIT BIMA) Cabang Sintang yaitu besar. Artinya bahwa minat menabung anggota di Koperasi Kredit Bina Masyarakat Cabang Sintang dikatakan besar dan sudah memiliki jumlah anggota penabung yang banyak

Pada analisis uji $t$, diperoleh $t_{\text {hitung }}$ variabel kualitas pelayanan (X) dan variabel minat menabung (Y) sebesar 3,824 dan nilai signifikansi sebesar 0,000 $<$ taraf kesalahan 0,05. Nilai $t_{\text {tabel }}$ ditentukan dengan cara melihat tabel distribusi $\mathrm{t}$ dengan taraf kesalahan 0,05 dan $\mathrm{dk}=\mathrm{n}-2$, dan ditemukan nilai $\mathrm{t}_{\text {tabel }}$ sebesar 1,984. Pengujian hipotesis 
dilakukan dengan membandingkan nilai $t_{\text {hitung }}$ dengan $t_{\text {tabel }}$, deketahui nilai $t_{\text {hitung }}$ $3,824>t_{\text {tabel }} 1,984$. Artinya pada penelitian ini menerima hipotesis alternative $\left(\mathrm{H}_{\mathrm{a}}\right)$ dan menolak hipotesis nol $\left(\mathrm{H}_{\mathrm{o}}\right)$, hal tersebut menunjukan bahwa terdapat pengaruh signifikan Kualitas Pelayanan terhadap Minat Menabung Anggota Koperasi Kredit Bina Masyarakat (KOPDIT BIMA) Cabang Sintang, Kabupaten Sintang.

Hasil penelitian ini diperkuatkan dengan penelitian yang sudah dilakukan oleh para peneliti sebelumnya yaitu penelitian yang dilakukan oleh Abidin (2009) penelitian dengan judul "Hubungan kualitas layanan dengan minat menabung nasabah PT. BRI di Kantor Cabang Ungaran”. Berdasarkan hasil penelitian, maka penelitian ini dapat disimpulkan: terdapat pengaruh yang positif dan signifikan antara kualitas layanan terhadap minat menabung nasabah PT. BRI di Kantor Cabang Ungaran, hal ini dibuktikan dari nilai analisis regresi sederhana menghasilkan koefisien korelasi rxy = 0,846 dengan $p=0,000$. Hasil tersebut menunjukan bahwa terdapat hubungan positif. Hasil R Square sebesar 0,715 artinya kualitas layanan memiliki sumbangan efektif sebesar 71,5 \% terhadap minat menabung nasabah. Kondisi tersebut menunjukkan bahwa tingkat konsistensi variabel minat menabung nasabah dapat diprediksi oleh variabel kualitas layanan sebesar 71,5\% dan sisanya sebesar 28,5\% ditentukan oleh faktor-faktor lain yang tidak diungkap oleh penelitian ini.

\section{PENUTUP}

Hasil nilai angket secara keseluruhan yaitu sebesar $78,40 \%$ dan dapat dilihat pada interval $61 \%-80 \%$ yaitu dikategorikan besar. Hal tersebut menunjukan bahwa kualitas pelayanan pada Koperasi Kredit Bina Masyarakat (KOPDIT BIMA) Cabang Sintang besar. Kemudian hasil nilai angket secara keseluruhan yaitu sebesar $69,06 \%$ dan dapat dilihat pada interval 61\%-80\% yaitu dikategorikan besar. Hal tersebut menunjukan bahwa minat menabung anggota pada Koperasi Kredit Bina Masyarakat (KOPDIT BIMA) Cabang Sintang besar.

\section{DAFTAR PUSTAKA}

Abidin, Z. dan Nurtjahjanti, H. 2009. "Hubungan kualitas layanan dengan minat menabung nasabah PT. BRI di Kantor Cabang Ungaran”. Jurnal. Ponegoro. Universitas di ponegoro. (Online). Volume 5, No 1. Tersedia:(http://eprints.undip.ac.id/1 0941/1/JurnalBariah.pdf)

Aswati, L. dan Sudarso, E. 2019. “Analisis Pengaruh Citra Merek, Kualitas Layanan dan Akses Lokasi Terhadap Minat Kunjung Kembali Pada Hotel Hongkong INN Singkawang" Jurnal Pendidikan. Volume 4, No 1 (http://jurnal.stkippersada.ac.id/jurna 
1/index.php/JPE, diakses 24 Juli 2020).

Angger,J. 2018. "Pengaruh Kualitas Pelayanan Dan Bagi Hasil Terhadap Minat Menabung Anggota Pada Koperasi Syariah Podo Joyo Sejahtera Blitar". Skripsi. Tulugagung. Fakultas Ekonomi Dan Bisnis Islam. (Online). Tersedia: (http://repo.iaintulungagung.ac.id/id/eprint/9188)

Baswir, R. 2015. Koperasi Indonesia. Yogyakarta: BPFEYOGYAKARTA.

Darmawan, A. 2019. "Analisis FactorFaktor Yang Mempengaruhi Minat Nasabah Menabung Di Bank Jateng Syariah". Jurnal Fokus Bisnis. Volume. 18, nomor. 01.

Enny. K. 2019. "Pengaruh Kualitas Pelayanan Koperasi Terhadap Kepuasan Anggota Koperasi Simpan Pinjam (Ksp) Bhakti Lestari Kecamatan Sungai Tebelian”. Jurnal Pendidikan Ekonomi. Volume 4, nomor $2 . \quad$ Tersedia: https://jurnal.stkippersada.ac.id/jurna 1/index.php/JPE/article/view/594/536

Handayani. R. T. 2018. "Pengaruh Kualitas Produk Tabungan dan Kualitas Pelayanan terhadap Minat Menabung Anggota Pada Koperasi Syariah AlMawaddah Ngunut Tulungagung".Skripsi.Tulungagung. Fakultas Ekonomi Bisnis Islam. (Online).

Tersedia:(http://repository.tulungagu ng.ac.id/7649/1.pdf)

Jajang, W. 2011. "Pelayanan Dan Manfaat Koperasi, Serta Pengaruh Terhadap Partisipasi Anggota". Jurnal FPIPS/Pendidikan Ekonomi. (Online). Volume 2, No 1. Tersedia: (http://jurnal.upi.edu/file/Jajang.pdf).
Kholid, I., dan Rahayu, M., 2014. "Penilaian Kesehatan Koperasi Simpan Pinjam Berdasarkan Peraturan Menteri Koperasi Dan Usaha Kecil Dan Menengah Republic Indonesia Nomor 14/PER/M. KUKM/XII/2009”. Jurnal administrasi bisnis. (Online). Volume.15 nomor. 2. Tersedia : (http://administrasibisnis.studentjour nal.ub.ac.id/index.php/jab/article/vie w/664)

Lubis, S, A. dan Andayani ,R, N. 2017. "Pengaruh Kualitas Pelayanan (Service Quality) Terhadap Kepuasan Pelanggan PT. Sucofindo Batam". Jurnal Administrasi Bisnis. Batam. (Online). Volume 1, No 1.

Mubarak, Z. Wahjoedi. dan Mardono. 2017. "Pengaruh Tingkat Pengetahuan Ilmu Ekonomi Dan Pemanfaatan Bank Mini Sekolah Terhadap Minat Menabung Siswa Kelas XI IPS SMA Negeri 2 Malang". Jurnal pendidikan ekonomi. Malang. Universitas Negeri Malang. (Online). Volume 5, No 1.Tersedia: (http://journal2.um.ac.id/index.php/j pe/article/view/1593/879)

Mintarja, E. 2017. "Hubungan Pengajaran Mata Kuliah Ekonomi Islam terhadap Minat Mahasiswa Menabung di Bank Syariah". Jurnal STIE. Jakarta (Online). Volume 1, No 2. Tersedia:(http://journal.unj.ac.id/unj/ index.php/hayula/article/view/1916)

Nugroho. S. A. 2018. "Pengaruh Kualitas Pelayanan, Tingkat Kepercayaan dan Minat Menabung terhadap Kemantapan Keputusan Menabung Nasabah di Bank Syariah". Skripsi. Semarang. Fakultas ekonomim. Tersedia:(http://erepository.perpus.ia insalatiga.ac.id/4822/1/Skripsi\%20Fi 
ks\%20CD.pdf, diakses 24 Mei 2020).

Pola Kebijakan Pengurus (POLJAK). 2020. Sintang-Kalimantan Barat

Sarwita, A. H. 2017. "Pengaruh Kualistas Pelayanan Dan Promosi Terhadap Keputusan Nasabah Untuk Menabung (Studi Kasus Pada Permuda BPR Majalengka)". Jurnal Manajemen dan Akuntansi. Volume 4. Nomor 1. (http://jurnal.unma.ac.id/index.php/ mk/article/view/504, diakses 31 maret 2020)

Sumantri, B. 2014. "Pengaruh Kualitas Pelayanan dan Produk Pembiayaan Terhadap Minat dan Keputusan Menjadi Nasabah di Bank Syariah". Jurnal ekonomi. Online. Volume 10, nomor Tersedia:(https://journal.uny.ac.id/in dex.php/economia/article/view/750,d iakses 16 Juli 2020).

Tyas, R. R. dan Setiawan, A., 2012. "Pengaruh Lokasi Dan Kualitas Pelayanan Terhadap Keputusan Nasabah Untuk Menabung Di BMT Sumber Mulia Tuntang". Jurnal. negeri. Volume 3, Nomor 2. (http://C:/Users/gc/Pictures/JURNA L\%20REFERENSI/Pengaruh_Lokas i_dan_Kualitas_Pelayanan_terhadap _Ke.pdf)

Undang-Undang Republik Indonesia Nomor 25 Tahun 1992 Tentang Perkoperasian. 1992. Jakarta. 